\title{
Correction to: Genome-resolved metagenomics of sugarcane vinasse bacteria
}

\author{
Noriko A. Cassman ${ }^{1}$, Késia S. Lourenço ${ }^{1,2}$, Janaína B. do Carmo ${ }^{3}$, Heitor Cantarella² and Eiko E. Kuramae ${ }^{\text {** }}$
}

\section{Correction to: Biotechnol Biofuels (2018) 11:48 https://doi.org/10.1186/s13068-018-1036-9}

The original version of the article contained a mistake. The accession number has been incorrectly published in the "Availability of data and materials" section.

The number is given below and has been corrected with this erratum.

The datasets generated and analysed during the current study are available in the MG-RAST repository with identification numbers described in Additional file 4 .

The NCBI shotgun metagenomes are BioProject id: PRJNA435511. Draft bacterial genomes are available at https://zenodo.org/record/1194340 (DOI: 10.5281/ zenodo.1194340).

\section{Author details}

${ }^{1}$ Department of Microbial Ecology, Netherlands Institute of Ecology NIOOKNAW, Wageningen, Netherlands. ${ }^{2}$ Soils and Environmental Resources Center, Agronomic Institute of Campinas, P.O. Box 28, Campinas, SP 13012-970, Brazil.

3 Environmental Science Department, Federal University of São Carlos, Sorocaba, SP 18052-780, Brazil.

The original article can be found online at https://doi.org/10.1186/s1306 8-018-1036-9.

\section{Publisher's Note}

Springer Nature remains neutral with regard to jurisdictional claims in published maps and institutional affiliations.

Published online: 03 October 2018

\section{Reference}

1. Cassman NA, Lourenço KS, do Carmo JB, Cantarella H, Kuramae EE. Genome-resolved metagenomics of sugarcane vinasse bacteria. Biotechnol Biofuels. 2018;11:48. https://doi.org/10.1186/s13068-018-1036-9.

\footnotetext{
${ }^{*}$ Correspondence: e.kuramae@nioo.knaw.nl

${ }^{1}$ Department of Microbial Ecology, Netherlands Institute of Ecology

NIOO-KNAW, Wageningen, Netherlands

Full list of author information is available at the end of the article
} 